\title{
The Islet Without Name (Danube River) in summer-autumn season (2015 and 2016)
}

\author{
Andreea-Florentina Marin \\ Faculty of Geography, University of Bucharest \\ andreea.marin09@yahoo.com
}

\begin{abstract}
The Islet Without Name is on the Danube River, located near the Romanian bank, between $\mathrm{km} 493.3$ and $\mathrm{km} \mathrm{471.4}$. Representing one of the most recent fluvial islet on the Danube River, the Islet Without Name began to form in the last 30 years. If, initially, in the sector where the islet is currently located, only a sandy bar emerged in the summer-autumn seasons, now is a permanent landform, covered by forest vegetation. In 2015 and 2016, several field campaigns were carried out to geomorphological changes under certain hydrometeorological conditions. The results obtained shows the continuous dynamism of this fluvial landform.
\end{abstract}

Keywords: Islet Without Name, Danube River, summer-autumn season, field observations

\section{INTRODUCTION}

Located near the Romanian bank, between $\mathrm{km}$ 493.3 and $\mathrm{km} \mathrm{471.4,} \mathrm{the} \mathrm{Island} \mathrm{Without} \mathrm{Name} \mathrm{is}$ one of the most recent river islets on the Danube River. Like any other fluvial landforms, the size is constantly changing under the influence of water level variations, flow and drainage velocity of water, currents and waves (Munteanu et al., 2009). It presents a specific microrelief. For example, the banks are higher than the central part, where there are small and abandoned lakes (Photo 1).

The Danube's Islands, implicitly, the Islet Without Name, show an important role from the biotic point of view. Danube level variations, the variety of microrelief and climatic conditions allow the installation of a large number of plant species (Munteanu et al., 2009). The Islet Without Name is predominantly covered with willow vegetation (Salix alba) and popular species (Populus alba, Populus nigra).

Also, it is "the home" for many invertebrate and vertebrate species, ensuring feeding, nesting and living conditions for many species of migratory birds (Photo 2), passenger or sedentary. For these reasons, the islet is part of the Natura 2000
Ecological Network and is included in the Special Protection Area (SPA) named ROSPA0090 Ostrovu Lung-Gostinu $($ area $=2489$ ha $)$.

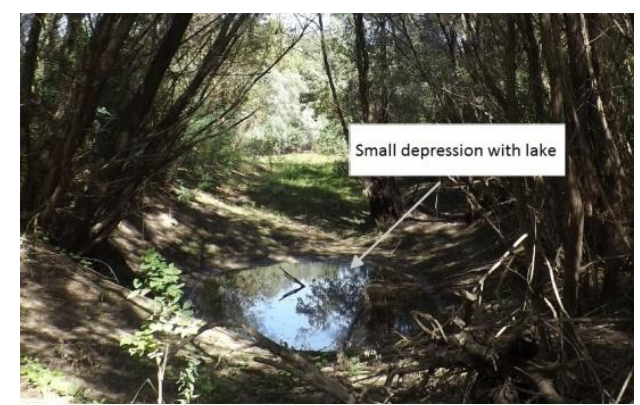

Photo 1 The Islet Without Name - small depression with lake (August 31, 2015)

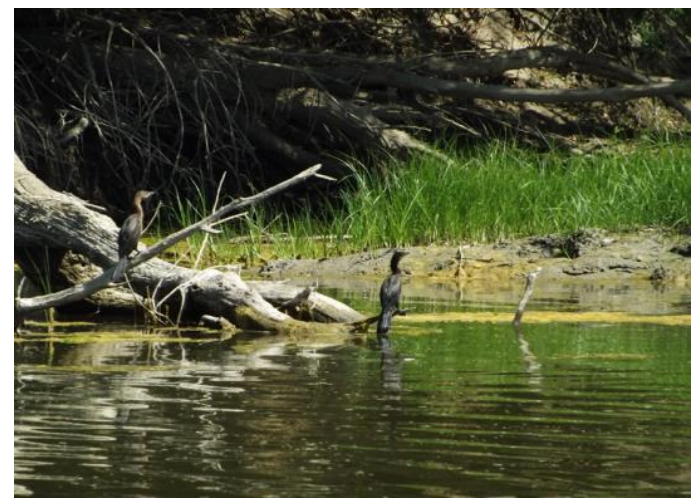

Photo 2 The Islet Without Name - Cormorants (August 8, 2015) 


\section{FROM HISTORICAL MAPS AND SATELLITE IMAGES TO REALITY}

Historical data sources, such as old maps analysed in Geographical Information Systems (GIS) represent one of the important resources for identification, localization and change analysis of geographic features. Drawing up a historical evolution of the Danube's Islands can be achieved from historical maps. But this is not valid for the Islet Without Name, whose recent age allows it to follow its evolution only through new mapping techniques.

Numerous International Earth monitoring and satellite mapping programs have been carried out so far by various governments and institutions. Among the most well-known and accessible to all specialists are: the Landsat satellite program and the Copernicus satellite program. Thus, Landsat and Sentinel 2A satellite images were used in this study.

The information extracted from the satellite images was validated and complemented by data from the field campaigns, carried out in the years 2015 and 2016. There were realized: i) visual observations, which materialized by identifying "in situ" the bed fluvial landforms and obtaining a rich photographic material, and ii) measurements with GPS, which consisted in mapping the water line near the village of Gostinu, Gostinu beach and the Islet Without Name. In 2015, we used a Garmin GPSmap 60CS, a device with an accuracy level of less than $3 \mathrm{~m}$, and in 2016 and 2017 a Trimble Geo7 device was used, the precision of which could reach up to $+/-10 \mathrm{~cm}$.

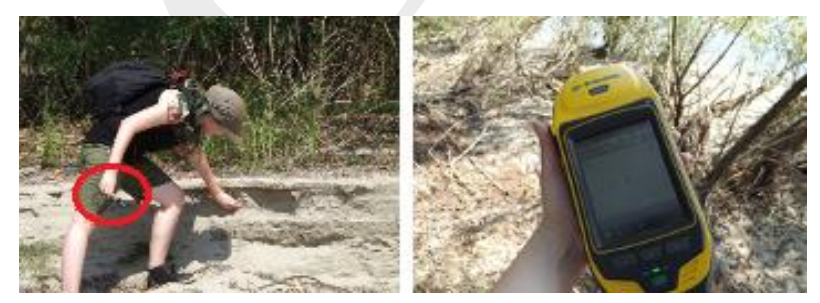

Photo 3 GPS devices used in field campaigns

\section{ISLET WITHOUT NAME - PAST AND PRESENT}

A careful monitoring of the islet on Landsat satellite imagery from 1990 and 1991, highlights the fact that in the sector where the islet is currently located, temporary fluvial landforms such as a sandy bar (Figure 1) can only be identified in the summerautumn seasons. Unfortunately, the poor spatial resolution of Landsat's satellite imagery at that time and the lack of images for some years, because of various technical reasons, make it difficult to detect the outline of this islet and the moment when it became a permanent geomorphological landform.
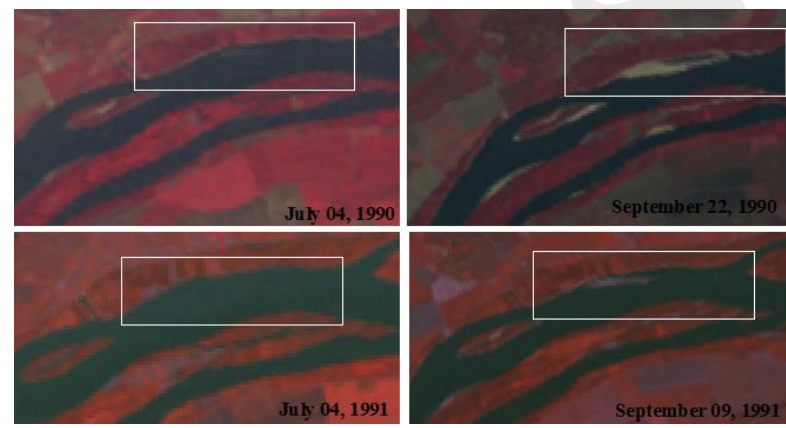

Figure 1 The white rectangle indicates the sector where The Islet Without Name is located

At present, the islet has an area of about $0.19 \mathrm{~km}^{2}$ and a simple aspect, with a strong elongated shape. In dry years, during summer, as a result of the decrease in Danube's water level, this islet merges partially with the left bank; so the connection between the islet and the Gostinu beach is made through a strip of sand (Photo 4).

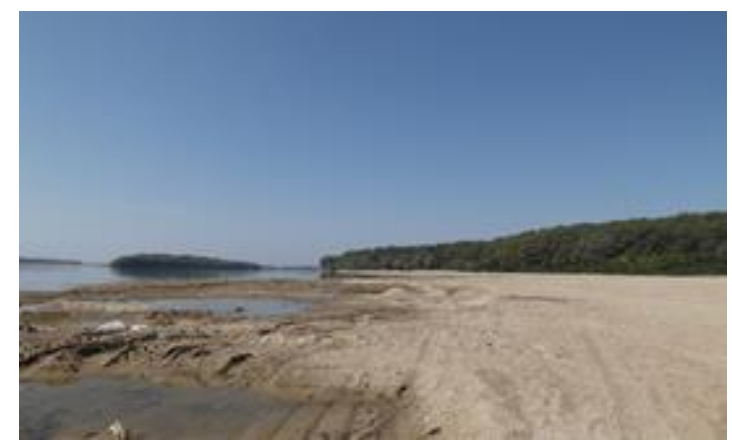

Photo 4 Strip of sand which link Gostinu beach and the Islet Without Name (September 20, 2015)

During two years (2015 and 2016), numerous field observations and measurements were carried out in the Danube sector, near Gostinu village, especially on the Islet Without Name. Both in 2015 and in 2016, after a long period of high temperatures and lack of precipitation, the level of the Danube quotas fell sharply. 2015 was a particular 
year, when Europe, especially its central-eastern part (including the territory of Romania), was hit by a severe drought. The summer of 2015 was characterized by daily temperatures with values of 2 to $3^{\circ} \mathrm{C}$ higher than the seasonal average, lack of precipitation and much higher evapotranspiration compared to normal limits (Van Lanen et al., 2016). All of these attracted many effects on river transport, hydrological energy, fauna and vegetation, crops, and even human health. In the context of these climatic conditions that persisted for a long time, there was an alarming decrease in hydrological parameters on several Danube sectors, which in turn influenced the riverbed morphology. Between June and September 2015, liquid and solid flows had a general downward trend, with minimum values being recorded in September. On September 10, 2015, the Danube's flow at the entrance into the country (Baziaş section) was $2300 \mathrm{~m}^{3} / \mathrm{s}$, below September's multiannual average of $3800 \mathrm{~m}^{3} / \mathrm{s}$ (INHGA, 2015). At the Giurgiu station, the value of $2400 \mathrm{~m}^{3} / \mathrm{s}$ was recorded. On the same day, the suspended solids reached the minimum value (in the course of the year under review) of $7.06 \mathrm{~kg} / \mathrm{s}$. The minimum level of Danube water at the Giurgiu hydrological station was also recorded in September: $-70 \mathrm{~cm}$. Although not below the historical level of $-144 \mathrm{~cm}$, registered in 2003, the decrease of the water level favored the emergence of the riverbed landforms. In Figure 2, it is noticed that the surface of Islet Without Name is larger, merging partly with the Romanian bank at both ends, but retaining a lateral channel filled with water. The width of Gostinu beach was measured in seven cross-sections, set at a distance of about 100 meters each (Figure 2). It is noted that in September 2015 the minimum width was $25 \mathrm{~m}$ and was measured along the first profile; As we moved eastwards (downstream), the beach grew, reaching a maximum width of 240 meters.

Unlike in 2015, in September 2016 hydrological parameters did not show such low values, the annual minimum values being recorded in another month. On September 17, 2016, when land measurements were made, the Danube's flow at the entrance into the country (Baziaş section) was of $3200 \mathrm{~m} 3 / \mathrm{s}$, below the $3800 \mathrm{~m}^{3} / \mathrm{s}$ multi-annual average of September (INHGA, 2016). At the
Giurgiu station, the value of $3520 \mathrm{~m}^{3} / \mathrm{s}$ was recorded. On the same day, the water level of the Danube, at the hydrological station Giurgiu, was of $39 \mathrm{~cm}$. In this hydrological context, the Islet Without Name showed significant changes in its surface or appearance (Figure 2), and the width of the beach reached up to $180 \mathrm{~m}$.

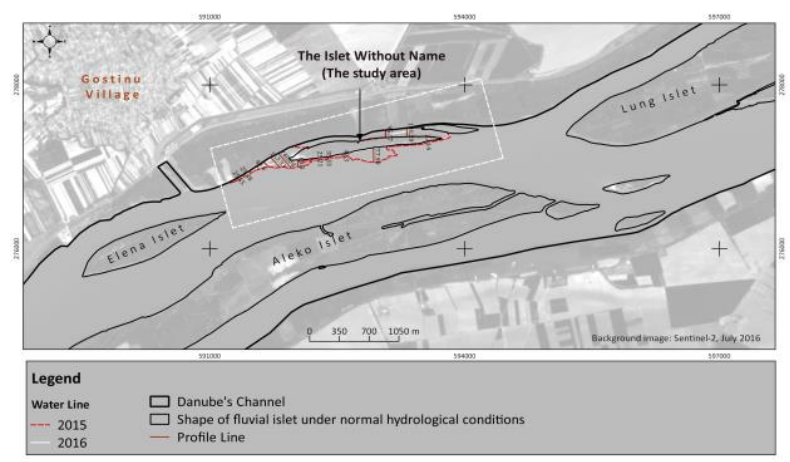

Figure 2 Changes in the evolution of Islet Without Name (2015-2016)

\section{CONCLUSIONS}

Fluvial islets are dynamic geomorphological formations. The shape and the size of Islet Without Name is constantly changing under the influence of hydrological and meteorological conditions. During only two years, large seasonal changes could be oberved on its aspect. This raises our curiosity to continue our observations in the next years and to find a pattern of evolution.

\section{ACKNOWLEDGEMENTS}

I would like to thank Andi Lazăr and Cristian Flueraru for their support with the GPS devices.

\section{REFERENCES}

Gautier, E., Gravel, S. (2006). „Multi-scale analysis of island formation and development in the Middle Loire River, France", în Werrity sediment dynamics and the hydromorphology of fluvial systems, Rowan, J.S., Duck, R.W. (eds), IAHS Publ 306, 179-187.

Gurnell, A.M., Petts, G.E., Hannah, D.M., Smith, B.P.G., Edwards, P.J., Kollmann J., Ward J.V., Tockner, K. (2001). Riparian vegetation and island formation along the gravel-bed Fiume Tagliamento, Italy. Earth Surface Processes and Landforms 26, 31-62.

INHGA, Hydrological forecasting for the Danube at the entrance to the country and the Romanian Sector 
[online] Available at: http://www.inhga.ro/web/ guest/ diagnoza_si_prognoza_dunare

Marin, A.-F. (2017). Studiul morfodinamicii ostroavelor în relație cu factorii de control fluviali prin tenici geospaţiale. Aplicație în sectorul dunărean GiurgiuOltenița. Teză de doctorat. Universitatea din București. Facultatea de Geografie.

Munteanu, C., Gheorghe, I.F., Plăiaşu, R., Stan, M., Tatole, V., Murariu, D. (2009). Flora și fauna ostroavelor de pe Dunăre. Editura „Green Steps”, Braşov.
Van Lanen, H.A.J.,Laaha, G., Kingston, D.G., Gauster, T., Ionita, M., Vidal, J.P., ..., Van Loon, A.F. (2016). Hydrology needed to manage droughts: the 2015 European case. Hydrol. Process., 30, 3097-3104.

Zanoni, L., Gurnell, A., Drake, N., Surian, N. (2008). Island dynamics in a braided river from analysis of historical maps and air photographs. River Research and Applications, 24 (8), 1141-1159. 